\title{
Karlovy Vary 2006
}

\author{
By Ron Holloway
}

Fall 2006 Issue of KINEMA

$41^{\text {st }}$ KARLOVY VARY INTERNATIONAL FILM FESTIVAL

"This year we have reason to celebrate two anniversaries," reflected Eva Zaoralová, artistic director of the $41^{\text {st }}$ Karlovy Vary International Film Festival (20 June-8 July 2006). "It was exactly 110 years ago, on 15 July 1896, that this famous spa town first set eyes on the Lumière brothers' invention and, fifty years later, the first postwar summer of 1946 saw the launch of the Karlovy Vary International Film Festival (KVIFF), back then also held in the neighbouring town of Mariánské Lázně (aka Marienbad)." Indeed, had not Karlovy Vary been forced by FIAPF (International Federation of Film Producers Associations) rules to alternate with Moscow for the A-Competition summer festival slot during the socialist era, then Eva Zaoralová and KVIFF president Jiři Bartoška might well be celebrating the spa festival's $60^{\text {th }}$ anniversary. And that would make Karlovy Vary-Mariánské Lázně one year older than Cannes!

Karlovy Vary, widely recognized by cineastes and festivaliers as one of the top events on the festival calendar, benefited mightily some years back when its tandem directors chose to bypass the specious glamour of other key festivals to place all their chips instead on films by promising independents and veteran directors from Central and Eastern Europe. In turn, the program has been fatten out with several award winners at Cannes, Berlin, and Venice. No wonder, then, that hundreds of young film fans backpack each summer to Karlovy Vary to devour six films a day, soak up spa concerts and rock bands, and sleep off the revelry in the parks if need be.

Some film professionals are also known to book their rooms at the Grand Hotel Pupp and other five-star hotels a year in advance, while newcomers marvel at the courtesies showered on them at restored inns and renovated guest houses. This year's balmy weather, of course, made Karlovy Vary all the more enjoyable. The rock-band concert by the popular "Festival Band" - spearheaded by Sofia's Stefan "Kita" Kitanov, Warsaw's Stefan Laudyn, and Karlovy Vary's own Stefan Ulrik - was a rousing, standing-room-only affair at an outdoor midnight gathering.

You could find anything and everything to your taste among the 266 entries from 63 countries at this year's KVIFF. The categories alone hinted of a veritable feast of quality auteur cinema in 21 different sections: Feature Film Competition, Documentary Competition, East of the West Competition, Official Selection Outof-Competition, Documentary Films Out of Competition, Special Events, Tribute to Jan Němec, Horizons, Another View, Forum of Independents, Variety Critics' Choice, Czech Films 2005-2006, Sundance at Karlovy Vary, Sundance Documentary Fund, Celluloid Dreams Presents Matthew Barney, Visions of Seven - Youth Through the Eyes of French Filmmakers, Focus on British Films, Tribute to John Huston, Tribute to Martin Holly, Midnight Screenings, and Treasures from the National Film Archive.

Personally, I was pleased to see that veteran Czech director Jan Němec was not forgotten. Film historians credit his Démanty noci (Diamonds in the Night, Czechoslovakia, 1964), the story of two boys escaping from a transport train during the Second World War and surviving in a forest on their wits, as one of the key films of the Czech New Wave. A year later, he directed the equally important $O$ slavnosti a hostech (The Party and Its Guests, Czechoslovakia, 1966), a political parable on the mechanism of power as mirrored in positions taken by prominent guests invited to a mysterious dinner party by an unknown host. Later, during the 1968 Soviet invasion of Czechoslovakia, Jan Němec secretly filmed the resistance among the Czech population, smuggled the footage out of the country, and had the material edited into Oratorium pro Prahu (Oratorium for Prague, 1968) for foreign television stations with Variety critic Gene Moskowitz speaking the commentary. His highly critical short film subsequently banned, Němec was blacklisted and in 1974 forced to leave the country to work in Sweden and West Germany. At KVIFF 2006 Němec presented his new experimental film, Toyen, a homage to a woman painter with the pseudonym Toyen (1902-1980), who had hid poet Jindřich Heisler in her bizarre flat in the Prague suburb of ?i?kov during the war. More of a fictional, avant-garde mesh of images and associations than a factual documentary on the surrealist painter, Toyen was well received at Karlovy Vary and deserves further exposure on the international festival circuit. 
Karlovy Vary opened with Kim Ki-duk's Shi gan (Time, Korea), the rather bizarre story of a young wife in a happy marriage, who nonetheless fears that her husband might one day tire of her face, so she opts for plastic surgery to remake herself into a "new woman" - with foreseeable complications. A regular at KVIFF, Kim Ki-duk was honoured in 2002 with a retrospective tribute and has returned faithfully with a new film each year ever since. The festival closed with Debbie Isittová's delightful Confetti (UK) - a comic fiction-documentary about three young British couples aching to win "the most original wedding of the year" awarded by a fictitious "Confetti" magazine. Since each couple has a different hangup - Hollywood nuts, tennis buffs, nudist lovers - it adds to the goofy merriment.

Karlovy Vary 2006 hit pay-dirt by inviting the prestigious Sundance Film Festival to present past award winners, both features and documentaries, from the festival archive. This tip-of-the-hat paid off on awards night, when Laurie Collyer's Sherrybaby (USA), the hit of the Sundance festival last January, was awarded the Crystal Globe, while the film's lead actress, Maggie Gyllenhaal, received the prize for Best Actress. As much heart-rending melodrama as it is hard-hitting rehabilitation documentary, Sherrybaby chronicles the efforts of a young mother to win back the affections of her little daughter upon being released from prison for drug abuse. Family intrigues over who should have care of the sensitive young daughter eventually upset the apple-cart just when Sherry (Maggie Gyllenhaal) seems to be getting a new hold on her life.

Jan Hřebejk's Kráska v nesnázích (Beauty in Trouble, Czech Republic) was awarded a share of the Special Jury Prize. Inspired by one of Robert Graves's sad love poems with the same title (his poetry is generally regarded as among the finest produced in the English language during the $20^{\text {th }}$ century), Beauty in Trouble sketches the dilemma of a young wife and mother (Ana Geislerová) torn between two loves - on the one side for her beloved but luckless husband, on the other for an elegant Czech-Italian gentleman who can offer security for herself and her two children: her dilemma is heightened even more when family members interfere. A finely crafted social drama, this is the sixth time that director Jan Hřebejk has collaborated with screenwriter Petr Jarchovský and cameraman Jan Malír on the team's favourite theme of love and redemption as interpreted in a typical Czech community and played out against traditional Czech mores. "My people are all first class professionals," said Jan Hřebejk in an interview. "I don't see any reason why I should change any of them when they are a huge advantage to me."

The other half of the Special Jury Award went to Ivan Cherkelov and Vassil Zhivkov's Obarnata elha (Christmas Tree Upside Down, Bulgaria-Germany), a touching omnibus tale linking six different stories around the theme of a towering spruce tree cut down in the mountains to serve as Sofia's community Christmas Tree. As the festive holiday approaches, young and old protagonists in each of the stories are faced with the question of the meaning of life, and how they can come to terms with loneliness, disappointments, and bitter twists of fate. Seldom has a Bulgarian feature film taken the pulse of a post-socialist society that is still wrestling with social and political forces that have turned their lives "upside down."

Other entries that deserve mention for documented historical content were Alexander Rogozhkin's Peregon (Transit, Russia) and Ensieh Shah-Hosseini's Shab bekheir farmandeh (Goodbye Life, Iran). In Alexander Rogozhkin's Transit the setting is Chukotka (aka Chukchi) in northeastern Siberia in 1942 at the height of the Second World War. As the story goes, the Soviet Union, short of aircraft, collaborated with the United States on an unusual lend-lease program that brought old fighter planes across the Bering Strait to be "repainted" with red stars for Soviet war use. All well and good, save for the exaggeration that the Yank pilots flying from Alaska happen to be women aviators! In Ensieh Shah-Hosseini's Goodbye Life the period is the opening salvo of the Iraq-Iran War in 1980-82, when the fronts changed hands in a bloody and bewildering maze of suffering and death. The terrors of the war are seen through the eyes of a woman reporter who has gone to the battlefield for a curious and puzzling personal reason: as a fragile individual prone to suicide, she uses the war experience as a form of questionable "psychotherapy"! All the same, the devastation on the landscape reaped by the war with Iraq - a taboo theme in Iranian cinema until only recently - is clearly visible in Goodbye Life, a conscientious film that deserves further festival exposure.

The Documentary Competition was one of strongest in recent memory. In the over 30-minute category the prize was shared by Timo Novotny's Life in Loops - A Megacities RMX (Austria) and Juan Carlos Rulfo's En el hoyo (In the Pit, Mexico), documentaries that appeared to be two sides of the same coin. As the title hints, Timo Novotny's Life in Loops is a "remix" of passages taken from Michael Glawogger's award-winning 
Megacities (Austria, 1988), an eye-catching portrait of teaming life in four great cities: Bombay, New York, Moscow, and Mexico. And Juan Carlos Rulfo's In the Pit, awarded the top prize in the World Documentary Competition at this year's Sundance Film Festival, chronicles the everyday of workers as they go about the risky task of constructing a freeway in Mexico City. In the under 30-minute category the prize went to Andreas Horváth's Views of a Retired Night Porter (Austria), an updated profile of the same watchdog porter who had epitomized the malevolence of communist surveillance in Krzysztof Kieślowski's classic documentary $Z$ punktu widzenia nocnego portiera (Night Porter's Point of View, Poland, 1977). Guess what? Despite all that's happened over the past 30 years, the old watchdog still adheres to the misguided methods of the good old days!

As for my own preference in the Documentary Competition, I was particularly taken by Sergei Loznica's powerful Blokada (Blockade, Russia). The first film to document the 900-day blockade of Leningrad that began on 8 September 1941 and lasted until 1 March 1944, Blockade portraits the sufferings and deaths of more than a million inhabitants in mute images without dialogue or commentary. Only street sounds are added to animate the footage with appropriate undertones. Running at 52 minutes, the film was edited and reassembled from approximately four hours of film footage made available to Sergei Loznica from a Russian film archive. "There is much more footage still to be found in the archive, said Loznica in an interview. "But this was all I was allowed to see and use." Two other documentaries impressed for their authenticity as chronicles of life and times among a people with rich cultural traditions. In Marko Škop's Iné svety (Other Worlds, Slovakia-Czech Republic) the focus is on the East Slovak village of Saris, where communities of Ruthenians, Gypsies, and Jews live peacefully side by side. The film deservedly received a Special Mention from the international jury. And in Harutyan Khachatyan's Poeti veradardze (Return of the Poet, Armenia) the story of Jivany, a legendary itinerant poet-balladeer who lived at the turn of the $19^{\text {th }}$ to $20^{\text {th }}$ centuries, is rendered in a poetic context. When a sculptor has finished his monumental tribute to the poet, he mounts it on a truck and travels from Yerevan to Jivany's birthplace. Along this surreal odyssey from the present into the past, the local populace sing the poet's traditional texts against a mystical landscape.

Several films in the East of the West Competition (a forum for films from Central and Eastern Europe) could easily have contended for top awards at Karlovy Vary had they not already done so at other international film festivals. Among these was Alexei Gherman Jr's Garpastum (old Latin for Ball Game, Russia), a haunting sketch of pre-World War One days that opens with a fascinating scene of young Serb anarchist Gavrilo Princip on his way to assassinate Austrian Archduke Francis Ferdinand in Sarajevo on 28 June 1914. Another was Yury Moroz's Tochka (The Spot, Russia), a hard-hitting documentary about the miserable lot shared by three Moscow street prostitutes under the severe hand of pimps and cops. Also, Nurbek Egen's Sunduk predkov (The Wedding Chest, Kirgizstan-Russia-France-Germany) won critical praise as a quaint comedy about a naive young man returning home from Paris to his native Kirgiz village with a French girlfriend on his arm - only to discover that his mother has already prepared the wedding chest for his marriage to a native girl of her choice.

The Prize for Best Film was awarded to Milena Andonova's Maimuni prez zimata (Monkeys in Winter, Bulgaria-Germany), an interwoven tale about the fate of three pregnant women in three different decades the $1960 \mathrm{~s}$, the $1980 \mathrm{~s}$, and the 2000s. A film that also accurately mirrors the country's social and political conditions during those times, Monkeys in Winter features fine acting performances by Bonka Ilieva-Boni, Diana Dobreva, and Angelina Slavova in the respective stories. It should be added that director Milena Andonova, along with her producer Nevena Andonova, are daughters of the late Metodi Andonov, whose Kozijat rog (The Goat Horn, 1972) still ranks as the greatest box office hit in the history of Bulgarian cinema. By an odd coincidence the Special Mentions in East of the West were given to films with similar themes. In Szabolcs Hajdu's Feher tenyer (White Palms, Hungary) a one-time gymnast prodigy returns to Budapest from Canada to compete again in a tournament - and find himself. And in Oleg Novković's Sutra ujutru ( Tomorrow Morning, Serbia \& Montenegro) a man returns from Canada to Belgrade to celebrate his wedding with family and friends - only to experience a world of contradictions.

One entry in East of the West should not be missed, but don't let its odd title confuse you. Corneliu Porumboiu's A fost sau n-a fost? (12:08 East of Bucharest, aka Did It Happen or Not?, Romania). [More on this film in my Cannes Sidebars report in this issue.] 
Following the close of the Karlovy Vary film festival, a selection of Central and Eastern European entries were programmed from July 9 to 19 in two Prague venues, the Aero and the Světozor, under the title "Echoes of the $41^{\text {st }}$ KVIFF." The series included Alexander Rogozhkin's Transit (Russia), Andrzej Baranski's Several People, Little Time (Poland), Alexei Gherman Jr's Garpastum (Russia), Milena Andonova's Monkeys in Winter (Bulgaria), and Ode to Joy (Poland) by the directorial trio of Anna Kazejakova-Dawidova, Jan Komasa, and Maciej Migas. Thus Karlovy Vary is expanding its mission to guarantee Czech exhibition of key festival entries from neighbouring countries as well.

\section{References}

AWARDS

INTERNATIONAL COMPETITION

Crystal Globe - Grand Prix

Sherrybaby (USA), dir Laurie Collyer

Special Jury Prize - ex aequo

Kráska v nesnázích (Beauty in Trouble, Czech Republic), dir Jan Hřebejk

Obarnata elha (Christmas Tree Upside Down, Bulgaria-Germany), dir Ivan Cherkelov, Vassil Zhivkov

Best Director

Joachim Trier, Reprise (Norway)

Best Actress

Maggie Gyllenhaal, Sherrybaby (USA), dir Laurie Collyer

Best Actor

Andrzej Hudziak, Pare osob, maly czas (Several People, Little Time, Poland), dir Andrzej Baranski

Special Mention

L'enfant d'une autre (This Girl Is Mine, France), dir Virginie Wagon

DOCUMENTARY COMPETITION

Best Long Documentary - ex aequo

Life in Loops (A Megacities RMX, Austria), dir Timo Novotny

En el hoyo (In the Pit, Mexico), dir Juan Carlos Rulfo

Best Short Documentary

Views of a Retired Night Porter (Austria), dir Andreas Horváth

Special Mention

Iné svety (Other Worlds, Slovakia-Czech Republic), dir Marko Škop

\section{EAST OF THE WEST COMPETITION}

Best Film

Maimuni prez zimata (Monkeys in Winter, Bulgaria-Germany),

dir Milena Andonova

Special Mention - ex aequo

Feher tenyer (White Palms, Hungary), dir Szabolcs Hajdu

Sutra ujutru (Tomorrow Morning, Serbia \& Montenegro),

dir Oleg Novković

NON-STATUTORY AWARDS

International Critics (FIPRESCI) Prize

Valkoinen kaupunki (Frozen City, Finland), dir Aku Louhimies

Ecumenical Prize

El destino (Destiny, Argentina-Spain), dir Miguel Pereira 
Don Quixote Prize (FICC - International Federation of Film Clubs)

Reprise (Norway), dir Joachim Trier

Special Mention

Shab bekheir farmandeh (Goodbye Life, Iran), dir Ensieh Shah-Hosseini

Czech Television Award - Independent Camera Prize - Forum of Independents

Play (Chile-Argentina), dir Alicia Scherson

Právo Audience Award

Iné svety (Other Worlds, Slovakia-Czech Republic)

dir Marko Škop

Awards for Outstanding Artistic Contribution to World Cinema

Jan Němec, Czech Republic

Andy Garcia, USA

Robert Shaye, USA

\section{Author Information}

Ron HOLLOWAY (1933-2009) was an American critic, film historian, filmmaker and correspondent who adopted Europe as his home in the early fifties and spent much of his life in Berlin. He was an expert on the study of German cinema and against all odds produced, with his wife Dorothea, the journal German Film, keeping us up-to-date with the work of directors, producers and writers and the showing of German films around the world.

In 2007, Ron Holloway and his wife were awarded the Berlinale Camera Award. Ron also received the Bundesverdienstkreuz (German Cross of Merit), Polish Rings, Cannes Gold Medaille, the American Cinema Foundation Award, the Diploma for Support of Russian Cinema and an honorary award from the German Film Critics' Association.

Ron was also a valued contributor to Kinema for the past fifteen years. 